\title{
Research on Export Potential and Trade Efficiency of China's Service Trade: An Empirical Study Based on the Belt and Road Countries
}

\author{
Zhenjuan Gao*, and Jingfeng Zhao \\ School of Economics and Management, Northwest University Xi’an, Shaanxi, China.
}

Keywords: Service trade; The belt and road; Export potential; Stochastic frontier gravity model

\begin{abstract}
Based on the construction of stochastic frontier gravity model, from 2008-2017, 14 the Belt and Road countries, its trade with China's service trade export potential and efficiency were studied. The empirical analysis results show that the GDP of partner countries, China's GDP, China's per capita GDP, bilateral distance have a significant impact on the volume of service trade. The average trade efficiency of China to the Belt and Road countries in 10 years is 0.4049 , which is at a low level, and there are gaps among various countries. Finally, the paper puts forward corresponding suggestions for increasing the export potential of service trade and expanding the tradable space between China and the countries along the Belt and Road.
\end{abstract}

\section{Introduction}

In 2013, leader of China proposed the construction of the Belt and Road initiative, which brought new opportunities for economic and trade cooperation between China and the countries along the route. As of the end of March 2019, China has signed 173 cooperation agreements with 125 countries and 29 international organizations. The Belt and Road co-construction region has been extended from Asia and Europe to Africa, Latin America and South Pacific. So what is the service trade potential and trade efficiency between China and the Belt and Road countries? What are the influencing factors? It is necessary to measure the export potential of service trade between China and the Belt and Road countries, and further explore the potential expandable space for service trade. With the development of China's service trade continues to grow, it is necessary to study whether there is a loss of trade efficiency in China's service trade, thereby improving the efficiency of service trade exports, and contributing to reducing the service trade deficit. At the same time, strengthening service trade cooperation between China and countries along the Belt and Road has important practical significance for advancing the Belt and Road initiative and strengthening bilateral or multilateral service trade cooperation.

\section{Literature Review}

Researches on trade potential and trade efficiency have rich research results. Tinbergen (1962) [1] introduced a traditional gravity model in the field of international trade. The study found that the size of a country is directly proportional to trade flows, while the bilateral distance is opposite. Linnemann (1966) [2] added population variables to the traditional gravity model. Since then, a large number of scholars have used gravity models to study international and inter-country trade [3-8]. Farrell proposed a cutting-edge method for measuring technical efficiency, which became the basis for measuring efficiency. Aigner and Chu put forward a cutting-edge production function model, which defines two parts of the random disturbance term $\mathrm{v}$ and $\mathrm{u}$, where $\mathrm{v}$ is the uncontrollable part of the random disturbance term; $u$ is the artificially controllable "unnatural factor” technology loss Errors. Aigner Detal (1977) [9] proposed the establishment and estimation of a random frontier gravity model. Compared with the gravity model, there is not much literature on the analysis of trade potential by using the stochastic frontier gravity model. Wu (2003) [10] used stochastic frontier analysis to analyze the trade potential of various regions in China. Ravishankar and Stack (2014) [11] used stochastic frontier analysis to measure the efficiency of trade exports between 17 Western European countries and 10 new members. Tamini (2016) [12] 
uses a stochastic frontier gravity model to analyze trade potential and trade efficiency between North African countries. However, few scholars use the stochastic frontier gravity model to analyze the trade potential and efficiency of trade in services between China and the Belt and Road countries. Therefore, based on domestic and foreign research, this article selects 14 countries along the Belt and Road. Using FRONTIER4.1, and stochastic frontier analysis method to analyze panel data for 10 years from 2008 to 2017, analyze China's service export potential, trade efficiency and influencing factors to the countries along the Belt and Road. It also estimates the potential and efficiency of service trade, and predicts the expansion of service trade with countries along the Belt and Road, with a view to providing useful lessons for the improvement of China's service trade efficiency and the advancement of the Belt and Road initiative.

\section{Model Settings and Data Sources}

\subsection{Construction of the theoretical model}

This paper draws on Aigner Detal (1977) [9] 's stochastic frontier gravity model to construct a model of China's service export potential and trade efficiency to countries along the Belt and Road.

Its theoretical model is as follows:

$$
\begin{array}{r}
T_{i j t}{ }^{*}=f\left(X_{i j t}, \beta\right) \exp \left(x_{i j t}\right) \\
T_{i j t}=f\left(X_{i j t}, \beta\right) \exp \left(x_{i j t}\right) \exp \left(-u_{i j t}\right) \\
E_{i j t}=T_{i j t} / T_{i j t} *=\exp \left(-u_{i j t}\right) \\
\ln \left(T_{i j t}\right)=\ln f\left(X_{i j t}, \beta\right)+v i_{j t}-u_{i j t}
\end{array}
$$

where $i, j=1,2 \ldots ., N ; t=1,2 \ldots$ T. $T_{i j t}$ * is the "trade potential" of countries $i$ and $j$ in $t . T_{i j t}$ is the actual trade volume of country $i$ and $j$ under the influence of external "unnatural factors". $X_{i j t}$ is the main "natural factors" that affect the trade volume between the two countries, including the size of the two countries' economies, geographical distance, and whether they are critical.

\subsection{The specific form of the stochastic frontier gravity model setting}

The specific equation of the bilateral trade volume between the two countries is as follows:

$$
\ln T_{i j t}=\ln \left(X_{i t}\right)+\ln \left(X_{j t}\right)+\ln (d i s-i n t)+\ln (c r i)+v_{i t}-u_{i t}
$$

where $X_{i t}$ and $X_{j t}$ are the economic scale of countries $i$ and $j$ (f-GDP and f-pgdp are the GDP of partner countries and per capita GDP; c-GDP and c-gdp are China's GDP and per capita GDP); dis-int represents the geography of the two countries Distance, cri indicates whether the two countries are critical.

\subsection{Variable and data}

In view of the availability of data, this paper selects the relevant data of 14 major countries along the Belt and Road for 10 years from 2008 to 2017. The data comes from the WTO statistical database, WDI database, and CEPII database. The economic freedom index comes from the "Index of Economic freedom" compiled by The Heritage Foundation.

\section{The Regression Results of the Stochastic Frontier Gravity Model}

\subsection{Hypothesis testing of the stochastic frontier gravity model}

In order to ensure the preciseness and rationality, verified. This paper uses LR statistics to verify the model's trade function form and "trade efficiency", and uses constrained and unconstrained models to make null hypothesis judgments. We use the proportion of trade inefficiency in random disturbance to verify again, that is to test the $\gamma . \gamma$ is given by : 


$$
\gamma=\frac{\sigma_{u}^{2}}{\sigma_{v}^{2}+\sigma_{u}^{2}}
$$

here the $\gamma$ is close to 1 , indicating that the degree of trade potential is more affected by "unnatural factors". So, it is more reasonable to use the stochastic frontier analysis method to remove interference items; $\gamma$ is close to 0 , indicating that the degree of trade potential is less affected by "unnatural factors", using OSL is more appropriate. This paper uses LR statistics to test the random frontier gravity model. The results are shown in Table 1:

Table 1 Hypothesis test results of the stochastic frontier gravity model

\begin{tabular}{|c|c|c|c|c|c|c|c|}
\hline Null hypothesis & Constraint model & Unconstrained model & LR statistics & $\begin{array}{c}1 \% \text { critical } \\
\text { value }\end{array}$ & $\begin{array}{c}5 \% \text { critical } \\
\text { value }\end{array}$ & $\begin{array}{c}10 \% \text { critical } \\
\text { value }\end{array}$ & Test result \\
\hline $\begin{array}{c}\text { No trade } \\
\text { inefficiency }\end{array}$ & -177.18 & -57.13 & 240.1 & 8.273 & 5.138 & 3.808 & reject \\
\hline $\begin{array}{c}\text { Trade inefficiency } \\
\text { is constant }\end{array}$ & -177.18 & -145.16 & 64.04 & 5.412 & 2.706 & 1.642 & reject \\
\hline
\end{tabular}

NOTE: $\mathrm{LR}=-2\left[\ln \left(\mathrm{H}_{0}\right)-\ln \left(\mathrm{H}_{1}\right)\right]$

Table 1 shows the test results all significantly rejected the null hypothesis at the $1 \%$ level, indicating that inefficient exists in services trade, and the use of a stochastic frontier gravity model is reasonable; meanwhile, the trade inefficiency term is not constant, which also means a time-varying stochastic frontier gravity model can better estimate trade efficiency.

\subsection{The regression results of the stochastic frontier gravity model}

From the regression results of the stochastic frontier gravity model in Table 2: (a) The economic scale of trading partner countries has a significant impact, that is, the improvement of the economic level of the countries along the Belt and Road can effectively enhance and stimulate the demand for Chinese service trade products, and then promote China's service trade exports. (b) The level of trade in services depends not only on the scale of the economy but also on the per capita GDP of the two countries. After adding all the variables, the impact of the per capita GDP of the country is much greater than that of the partner country, which also shows that the per capita GDP of the country has increased, and more attention has been paid to the diversification of services, resulting in China's service trade becoming more diverse, promoting the export of China's service trade. (c) Bilateral distance is also one of the important factors influencing bilateral service trade. For every $1 \%$ increase in geographic distance between China and the countries along the Belt and Road, the volume of trade in services decreases by $0.51 \%$.

Table 2 Estimated export results of China's service trade to the countries along the Belt and Road

\begin{tabular}{|c|c|c|c|c|}
\hline variable & (1) & $(2)$ & (3) & (4) \\
\hline \multirow{2}{*}{ cons } & $-16.06^{* * *}$ & $-14.81^{* * *}$ & $-58.94^{* * *}$ & $167.98^{* *}$ \\
\hline & $(-8.09)$ & $(-4.55)$ & $(-16.99)$ & $(168.71)$ \\
\hline \multirow{2}{*}{$\ln (f-G D P)$} & $1.28^{* *}$ & $1.38^{* * *}$ & & $1.21^{* * * *}$ \\
\hline & $(-16.65)$ & $(-4.12)$ & & (14.12) \\
\hline \multirow{2}{*}{$\ln (\mathrm{c}-\mathrm{GDP})$} & $0.65^{* * *}$ & $0.64^{* * *}$ & & -28.23 \\
\hline & $(-5.43)$ & $(-4.84)$ & & $(-51.01)$ \\
\hline \multirow{2}{*}{$\ln$ (dis-int) } & $-0.70^{* * * *}$ & $-1.12^{* * * *}$ & $-0.29^{* * *}$ & $-0.51^{* * * *}$ \\
\hline & $(-7.99)$ & $(-3.14)$ & $(-2.97)$ & $(-2.80)$ \\
\hline \multirow{2}{*}{ cri } & & $2.03^{* *}$ & $4.20^{* * * *}$ & 0.97 \\
\hline & & $(-1.29)$ & $(-3.47)$ & $(0.10)$ \\
\hline \multirow{2}{*}{$\ln (f-p g d p)$} & & & $22.62^{* * *}$ & $0.52^{* *}$ \\
\hline & & & $(-15.74)$ & $(2.03)$ \\
\hline \multirow{2}{*}{$\ln (c-p g d p)$} & & & $4.44^{* * *}$ & $30.51^{* * *}$ \\
\hline & & & $(-5.39)$ & $(40.93)$ \\
\hline$\gamma$ & 0.95 & 0.89 & 0.95 & 0.87 \\
\hline sigma-squared & 2.12 & 0.96 & 1.89 & 0.68 \\
\hline log likelihood & -67.06 & -66.53 & -67.07 & -145.16 \\
\hline obs & 140 & 140 & 140 & 140 \\
\hline
\end{tabular}

Note: $*, * *$, and $* * *$ indicate significant levels at $10 \%, 5 \%$, and $1 \%$, respectively. 


\subsection{Estimation of service trade potential and trade efficiency}

The trade efficiency of this article is calculated from FRONTIER 4.1, and the results are shown in Table 3. Table 3 shows, the service trade efficiency value of China and the 14 major countries along the Belt and Road for the last ten years is 0.4049, which is lower than 0.5. China's service trade exports to major countries along the Belt and Road have 10 countries with an average trade efficiency of more than 0.5 in 4 countries, 5 countries in the range of $0.3-0.5$, and 2 countries in the range of 0.1-0.3. There are 3 countries with less than 0.1. In 2017, China's export potential of service trade to major countries along the Belt and Road reached $\$ 20.4$ billion, while the actual value of service trade in 2017 was only $\$ 12.582$ billion, accounting for $61.67 \%$, and the $\$ 7.818$ billion wasn’t released. In short, there is still room for the potential of service trade exports between China and the countries along the Belt and Road to be unleashed, and overall service trade efficiency is not high.

Table 3 shows that Czech Republic, Russia, and Singapore are the top three countries in the average efficiency of trade in services in the past ten years among the main countries along the Belt and Road. The Czech Republic actively responded to China's the Belt and Road initiative, signed a number of cooperation agreements and memorandums with China, and at the same time, imports of China's service trade rose steadily. Russia and China have always maintained a good cooperative relationship, and the geographical distance is closest to China, and there is a certain demand for China's service trade. Singapore with a high degree of service industry and China have a long history. The culture and language with the same origins as China have promoted China's exports of services to Singapore. Such as Slovenia, Croatia, and Lithuania are far from Eastern Europe, and they are relatively small, and trade in services is less efficient.

Table 3 China's service export efficiency and export potential to major countries along the Belt and Road

\begin{tabular}{|c|c|c|c|c|c|c|c|c|c|c|c|c|c|}
\hline country & 2008 & 2009 & 2010 & 2011 & 2012 & 2013 & 2014 & 2015 & 2016 & 2017 & $\begin{array}{c}\text { 10-year } \\
\text { average } \\
\text { efficiency }\end{array}$ & $\begin{array}{l}\text { Service Trade } \\
\text { Potential in } 2017 \\
\text { (\$million) }\end{array}$ & $\begin{array}{c}\text { Expandable } \\
\text { trade volume } \\
\text { in } 2017 \\
\text { (\$million) }\end{array}$ \\
\hline Singapore & 0.7533 & 0.7857 & 0.6879 & 0.7851 & 0.7839 & 0.7996 & 0.9541 & 0.8807 & 0.7736 & 0.7683 & 0.7972 & 10037.85 & 2325.85 \\
\hline Israel & 0.4672 & 0.1954 & 0.2308 & 0.1383 & 0.1240 & 0.1629 & 0.1643 & 0.1860 & 0.1413 & 0.2565 & 0.2067 & 2740.47 & 2037.47 \\
\hline Cyprus & 0.3338 & 0.2169 & 0.1813 & 0.1700 & 0.1442 & 0.1363 & 0.5195 & 0.2201 & 0.1758 & 0.1549 & 0.2253 & 393.84 & 332.84 \\
\hline Greece & 0.4548 & 0.3972 & 0.3003 & 0.2752 & 0.3000 & 0.3961 & 0.3449 & 0.2228 & 0.2125 & 0.2107 & 0.3115 & 1011.09 & 798.09 \\
\hline Russia & 0.6460 & 0.7203 & 0.8220 & 0.9858 & 0.9541 & 0.8561 & 0.8505 & 0.7725 & 0.9004 & 0.8871 & 0.8395 & 2294.09 & 259.09 \\
\hline $\begin{array}{c}\text { Czech } \\
\text { Republic }\end{array}$ & 0.8884 & 0.7724 & 0.9995 & 0.7425 & 0.8434 & 0.9227 & 0.9675 & 0.9497 & 0.8531 & 0.9042 & 0.8844 & 1071.63 & 102.63 \\
\hline Hungary & 0.4155 & 0.4396 & 0.5405 & 0.4001 & 0.2984 & 0.5298 & 0.3999 & 0.3940 & 0.3640 & 0.4143 & 0.4196 & 453.80 & 265.80 \\
\hline Poland & 0.6131 & 0.3582 & 0.3957 & 0.3976 & 0.3250 & 0.3296 & 0.3525 & 0.3113 & 0.3360 & 0.4301 & 0.3849 & 1067.31 & 608.31 \\
\hline Estonia & 0.4242 & 0.3533 & 0.5380 & 0.6621 & 0.6705 & 0.5994 & 0.6143 & 0.4962 & 0.5536 & 0.5632 & 0.5475 & 163.35 & 71.35 \\
\hline Latvia & 0.4592 & 0.4035 & 0.4965 & 0.6080 & 0.5336 & 0.4470 & 0.4562 & 0.3797 & 0.3715 & 0.3832 & 0.4539 & 133.09 & 82.09 \\
\hline Lithuania & 0.1017 & 0.0714 & 0.0407 & 0.0896 & 0.0430 & 0.1858 & 0.1221 & 0.1152 & 0.0779 & 0.1043 & 0.0952 & 210.94 & 188.94 \\
\hline Slovenia & 0.0284 & 0.0255 & 0.0227 & 0.0287 & 0.0348 & 0.0400 & 0.0445 & 0.0612 & 0.0491 & 0.0449 & 0.0380 & 490.22 & 468.22 \\
\hline Croatia & 0.0768 & 0.0901 & 0.0898 & 0.0837 & 0.1005 & 0.1035 & 0.0813 & 0.0953 & 0.0399 & 0.0624 & 0.0823 & 240.33 & 225.33 \\
\hline Bulgaria & 0.1842 & 0.2053 & 0.1800 & 0.1756 & 0.3677 & 0.3804 & 0.8408 & 0.4691 & 0.5975 & 0.4343 & 0.3835 & 92.10 & 52.10 \\
\hline Total & & & & & & & & & & & 0.4049 & 20400.10 & 7818.10 \\
\hline
\end{tabular}

Note: The expandable trade volume = trade potential value-trade actual value.

\section{Conclusions and Recommendations}

In this paper, by constructing a stochastic frontier gravity model, we estimate and compare the export potential and trade efficiency of service trade between China and major countries along the Belt and Road. The empirical results are as follows: (1) Among the "quality factors" of trading partner countries, the economic scale of the countries along the Belt and Road, the economic scale 
of China and the level of per capita GDP have a significant pulling effect on service trade exports, showing "demand creation". Geographical distance is also one of the important factors affecting bilateral trade in services. Whether China and the countries along the Belt and Road are critical is also positively related. (2) Measurement of service trade efficiency between China and major countries along the Belt and Road shows that the average efficiency of service trade between 2008 and 2017 is 0.4049 , which is lower than 0.5, which shows that China and the countries along the Belt and Road service trade is inefficient.

In order to further improve the efficiency of service trade export between China and the countries along the Belt and Road and deepen the potential of service trade export, China should further promote the continuous implementation of the Belt and Road initiative, actively reach consensus with the countries along the Belt and Road, and promote bilateral economic and trade cooperation; Further expand the intensity and scope of economic reform and opening up, insist on supply-side reforms, improve the level of economic development, and then release the "demand creation" effectiveness. We should actively advocate the Belt and Road, and two multilateral service trade agreements, and form a double multilateral preferential policy or agreement to eliminate the factor of inefficiency in service trade. Only in this way can the trade efficiency of service trade between China and the countries along the Belt and Road be continuously improved, the potential and space of service trade development can be continuously expanded, and a good situation of mutual benefit and win-win situation can be achieved.

\section{References}

[1] Tinbergen, J. Shaping the World Economy: Suggestions for an International Economic Policy. New York: The Twentieth Century Fund, 1962.

[2] Linnemann, H. An Econometric Study of International Trade Flows. Amsterdam North Holland, 1966

[3] Bergstrand. The Gravity Equation in International Trade: Some Microeconomic Foundations and Empirical Evidence. The Review of Economics and Statistics, 1985.

[4] Rao, M A, Liu, H, Mahmood, H. Pakistan's agricultural exports, determinants and its potential: an application of stochastic frontier gravity model. The Journal of International Trade \& Economic, 2017.

[5] Viorica, E D. Econometric Analysis of Foreign Trade Efficiency of E.U Members Using Gravity Equations. Procedia Economics and finance, 2015, 20: 670-678.

[6] Battese, G E, Coelli, T J. A Model for Technical Inefficiency Effects in a Stochastic Frontier Production Function for Panel Data, Empirical economics, 1995, 20: 325-332.

[7] Coelli, T. A Guide to Frontier Version 4.1: A Computer Program for Stochastic Frontier Production and Cost Function Estimation, CEPA Working Paper, 1996.

[8] Miankhel, A K, Kalirajan, K, Thangavelu, S M. Australia’s Export Potential an Exploratory Analysis Journal of the Asia Pacific Economy, 2014, 19: 230-246.

[9] Aigner, D, et al. Formulation and Estimation of Stochastic Frontier Production Function Models. Journal of Econometrics, 1977, 6: 21-37.

[10] Wu Yanrui. Export Potential and Its Determinants among the Chinese Regions,International Conference on Chinese Economy, 2003.

[11] Ravishankar, G, Stack, M. The Gravity Model and Trade Efficiency: A Stochastic Frontier Analysis of Eastern European Countries’ Potential Trade. World Economy, 2014, 37: 690-704.

[12] Tamini, L, et al. Trade Performance and Potential of North African Countries: An Application of a Stochastic Frontier Gravity Model.Cahiers De Recherche Create, 2016, 4: 1-37. 